\title{
BIOLOGICAL EVALUATION FOR SOME PLANTS USED FOR TREATMENT OF DIABETES AND HYPERLIPIDAEMIA IN RATS
}

\author{
El-Tellawy, F. M. ${ }^{(1)}$; Moustafa, O. A. ${ }^{(2)}$; Freig, Shadia, A. ${ }^{(2)}$ \\ and Yousef, Ghada, . $^{(3)}$ \\ 1) Institute of Environmental Studies and Research, Ain shams University. \\ 2) Faculty of Specific Education, Ain shams University. Dietation National \\ 3) Nutrition Institute, Cairo, Egypt.
}

\begin{abstract}
This study aimed to decrease blood sugar concentration and hyperlipidemia in rats using dry Cinnamon and fruits Amla. Diabetes can affect many different organ systems in the body and, over time, may lead to serious complications, which can be classified as microvascular or macrovascular. Microvascular complications include nervous system damage (neuropathy), renal system damage (nephropathy) and eye damage (retinopathy). Macrovascular complications include cardiovascular disease, stroke, and peripheral vascular disease, which may lead to bruises or injuries that do not heal, gangrene, and, ultimately, amputation.sixty six Male albino rats Spargue Dawley Strain weighing $(200 \pm 10 \mathrm{~g})$ were housed in well aerated cages under hygienic condition and fed on basal diet for one week for adaptation. Then rats were divided into three main groups as follows: The first main group (G1) (6 rats) was fed on basal diet (control negative group). The second main group (30 rats) fed on standard diet contained 10\% saturated fat to induce hyperlipidemic model, then hyperlipidemic rats were divided into 5sbgroups, each of six rats as follow; Subgroup (G2) fed on basal diet ( positive control group), subgroup (G3) fed on high fat diet containing $1 \%$ cinnamon, subgroup (G4) fed on high fat diet containing $1.5 \%$ cinnamon, subgroup (G5) fed on high fat diet containing 1\% amla and subgroup (G6) fed on high fat diet containing $1.5 \%$ amla. The third main group 30 rats were injected with alloxan (120 mg / $\mathrm{kg}$ body weight i.p.) to induce diabetes (Dhanabal et al., 2005), then diabetic rats were divided into 5subgroups, each of six rats as follow; subgroup (G7) fed on basal diet as positive control
\end{abstract}


group, subgroup (G8) fed on basal diet containing 1\% cinnamon, group(G9) fed on basal diet containing $1.5 \%$ cinnamon, subgroup $(\mathrm{G} 10)$ fed on basal diet containing $1 \%$ amla and subgroup(G11) fed on basal diet containing $1.5 \%$ amla. After 4 weeks serum biochemical parameters including glucose, liver function, and blood lipid profile were determined. It could be concluded that, feeding on Cinnamon and fruits Amla led to significant decrement in blood glucose level and lipids of positive group rats compared with diabetic and hyperlipidemic rats fed on basal diet. The reduction of glucose and lipids parameters were observed after one week of feeding gradually till the end of experimental period, also, significantly lower in total cholesterol, triglycerides, and total lipids in comparing to positive diabetic and hyperlipidemic rats fed on basal diet were observed.

Key words: hyperlipidemia - Diabetes- Cinnamon and fruits Amla.

\section{INTRODUCTION}

Diabetes mellitus is a chronic disease characterized by a deficiency in insulin production and its action or both. That leads to prolonged hyperglycemia with disturbances in most metabolic processes inside the human body. Untreated cases show severe tissue and vascular damage leading to serious complications such as retinopathy, neuropathy , nephropathy, cardiovascular complications and ulceration (Singab;2014). Elevated plasma glucose levels and abnormalities of carbohydrate and lipid metabolism, produce characteristic pathologic changes in the nerves and small blood vessels, and aggravation of atherosclerosis (Lee and Nieman, 2003). Since 1932, diabetes mellitus has been among the top 10 leading causes of death in America. It is a major cause of blindness, renal failure, congenital malformation, and lower extremity amputation, (American Diabetes Association, 2001) It is well known that patients with type 2 
diabetes mellitus (T2DM) are at increased risk of cardiovascular (CV) disease. Elevated plasma glucose levels that independently lead to increased cardiovascular risk, combined with associated comorbidities such as obesity, hypertension, and dyslipidemia, further contribute to the development of CV complications. ( Solun et al. (2013). The prevalence of coronary artery disease and peripheral vascular disease is twice as common among persons with diabetes, as compared with those without diabetes (American Diabetes Association,2001). Nephropathy is a common consequence of diabetes, with a high prevalence in patients with type 1 (15\%-25\%) and type 2 diabetes mellitus (T2DM; 30\%-40\%). Nephropathy is associated with a poor prognosis and high economic burden. The risk of developing nephropathy increases with the duration of diabetes, and early diagnosis and treatment of risk factors for nephropathy (e.g., tight control of glycemia and hypertension) can reduce the development and progression of diabetic nephropathy (Schernthaner and, Schernthaner ., 2013). Today we are witnessing a great deal of interest in the use of herbal remedies. Some consumers have become dissatisfied with conventional medicine. They perceive it as impersonal and expensive, and conventional drug therapy often has undesirable side effects. For many Americans, the medicinal use of plant extracts seems to be a more natural, less expensive way, and involving therapies that are more gentle and largely without side effects (Watson.2001). The use of traditional plant for diabetes mellitus is widely practiced in Middle East countries. The world health organization (WHO) has recommended that this should be encouraged, especially in countries where access to the conventional treatment of diabetes is not adequate (WHO, 1980). Beirao et al. (2005) showed that Emblica 
officinalis Gaertn or Phyllanthus emblica Linn, commonly known as Indian gooseberry or amla is arguably the most important medicinal plant in the Indian traditional system of medicine, the Ayurveda. Various parts of the plant are used to treat a range of diseases, but the most important is the fruit. The fruit is used either alone or in combination with other plants to treat many ailments such as common cold and fever; as a diuretic, laxative, liver tonic, refrigerant, stomachic, restorative, alterative, antipyretic, anti inflammatory, hair tonic; to prevent peptic ulcer and dyspepsia, and as a digestive. Preclinical studies have shown that amla possesses antipyretic, analgesic, antitussive, antiatherogenic, adaptogenic, cardioprotective, gastroprotective, antianemia, antihypercholesterolemia, wound healing, antidiarrheal, antiatherosclerotic, hepatoprotective, nephroprotective, and neuroprotective properties. In addition, experimental studies have shown that amla and some of its phytochemicals such as gallic acid, ellagic acid, pyrogallol, some norsesquiterpenoids, corilagin, geraniin, elaeocarpusin, and prodelphinidins B1 and B2 also possess antineoplastic effects. Amla is also reported to possess radiomodulatory, chemomodulatory, chemopreventive effects, free radical scavenging, antioxidant, anti-inflammatory, antimutagenic and immunomodulatory activities, properties that are efficacious in the treatment and prevention of cancer. This review for the first time summarizes the results related to these properties and also emphasizes the aspects that warrant future research to establish its activity and utility as a cancer preventive and therapeutic drug in humans ( Baliga et al., 2011 ). 
Krishnaveni and Mirunalin (2010) reported that Phyllanthus emblica Linn. (syn. Emblica officinalis), commonly known as Indian gooseberry or amla, family Euphorbiaceae, is an important herbal drug used in unani (Graceo - arab) and ayurvedic systems of medicine. The plant is used both as a medicine and as a tonic to build up lost vitality and vigor. Phyllanthus emblica is highly nutritious and could be an important dietary source of vitamin $\mathrm{C}$, amino acids, and minerals. The plant also contains phenolic compounds, tannins, phyllembelic acid, phyllembelin, rutin, curcum-inoids, and emblicol. All parts of the plant are used for medicinal purposes, especially the fruit, which has been used in Ayurveda as a potent rasayana and in traditional medicine for the treatment of diarrhea, jaundice, and inflammation. Various plant parts show antidiabetic, hypolipidemic, antibacterial, antioxidant, antiulcerogenic, hepatoprotective, gastroprotective, and chemopreventive properties.

\section{MATERIAL AND METHODS}

This study was carried out using Cinnamon and fruits Amla which purchased from local market in Cairo city. Cholesterol, casein, bile acids, kits and cholin choleride were purchased from El-Gomhoreria Co.

\section{Analytical methods:}

The prepared samples were subjected to the chemical analysis moisture, protein, fat and ash by the methods described by A.O.A.C. (1990). Crude fiber was measured using the method described by Kirk and Sawyer (1991). Total carbohydrates were determined using the method described by James (1995). 


\section{Biological investigation:}

\section{Experimental animals:}

Sixty six adult male albino rats 10-12 weeks old weighting between $200 \pm 10 \mathrm{~g}$. were housed individually in wire cages with wire bottoms and fed on basal diet for one week which consisted of protein (14\%), fat (4\%), salt mixture $(3.5 \%)$, vitamin mixture $(1 \%)$ choline-chloride $(0.25 \%)$ cellulose (5\%) and the remainder was starch. Reeves et al., (1993).

After feeding on basal diet for one weeks, six rats were randomly chosen as. first main group (G1) which was fed on basal diet (control negative group). the second main group which was injected with alloxan. (30 diabetic rats ) was devided into five subgroups each of six rats as follow ; subgroup $(\mathrm{G} 7)$ rats fed on basal diet (positive control group) ,subgroup (G8) fed on basal diet containing 1\% cinnamon ,subgroup (G9) fed on basal diet containing $1.5 \%$ cinnamon, subgroup (G10)fed on basal diet containing $1 \%$ amla, subgroup (G11) fed on basal diet containing 1.5\% amla .The third main group (30 rats) fed on standard diet contained 10\% saturated fat to induce hyperlipidemia then hyperlipidemic rats were divided into five subgroups each of six rats as follow; subgroup (G2) rats fed on basal diet (apositive control group). subgroup (G3) fed on high fat diet containing 1\% cinnamon. Subgroup (G4) fed on high fat diet containing $1.5 \%$ cinnamon. Subgroup (G5) fed on high fat diet containing 1\% amla. subgroup (G6) fed on high fat diet containing $1.5 \%$ amla. 


\section{Biological Evaluation:}

Blood samples were collected for blood glucose analysis every week and at the end of trials, the animals were sacrificed, under ether anaesthetized and blood samples were collected in clean dry centrifuge tube from hepatic portal vein. Serum was separated by centrifugation at 4000 r.p.m. for 10 minutes at room temperature then kept in plastic vials at-20c until analysis.

\section{Biochemical Analysis:}

Glucose was determined by enzymatic methods using kits according to Trinder (1969). Triglycerides in serum was determined colorimetrically according to Fossatip and Prancipel, (1982). Total cholesterol was determined by colorimetric method according to Allain( 1974).

AST and ALT activities were measured according to method described by Reitman and Frankel (1957

Alkaline phosphates (ALP) determination procedure based on calorimetric determination of ALP was preformed according to the method of Roy (1970).

\section{Statistical analysis:}

The results expressed as mean $\pm \mathrm{SD}$, using student $(\mathrm{t})$ test. The obtained results were analyzed to determine the degree of significances between different groups $(\mathrm{p} \leq 0.05)$ using one way analyzing of various (ANOVA) (SAS, 1988). 
J. Environ. Sci.

Institute of Environmental Studies and Research - Ain Shams University

\section{RESULTS AND DISCUSSION}

Blood glucose in diabetic rats fed on cinnamon and amla is illustrated in table (1) and fig (1)

serum blood sugar for healthy rats group (control negative) was $(84.0 \pm 3.28 \mathrm{mg} / \mathrm{dl})$. While,for untreated diabetic group (control positive) was $(329.66 \pm 15.08 \mathrm{mg} / \mathrm{dl})$. In most cases, serum blood sugar was decrease for diabetic group that treated with different doses of Cinnamon and Amla. The lowes resultst in serum blood sugar were recorded for group treated with $1.5 \%$ of Amla and $1.5 \%$ of Cinnamon. Even, significant differences were observed between them and control negative and positive groups.

Cinnamon is a herbal medication plant used widely for many diseases in the Middle East and ancient countries. Cinnamon Extract (CE) contains many active substances that modulate insulin sensitivity and acts as anti-diabetic medication. Diabetes mellitus is a disease characterized by disturbance in Carbohydrate and lipid metabolism. CE regulates the expression of genes related to lipid and carbohydrate metabolism in a way to control the metabolic disorders occur during diabetes (Soliman et al.2013).

Blood lipid profile was also affect by feeding with cinnamon and amla as shown in table(2),fig ( $2 a$ and $2 b$ ) serum cholesterol and triglycerides for healthy rats group (control negative) were $84.28 \pm 6.19$ and $70.27 \pm 3.78$ $(\mathrm{mg} / \mathrm{dl})$ respectively. . While, the serum for untreated diabetic group (control positive) were $304.17 \pm 30.25$ and $140.07 \pm 3.73(\mathrm{mg} / \mathrm{dl}$ ), respectively. In most cases, serum cholesterol and triglycerides were decrease for diabetic group that treated with different doses of Cinnamon and Amla. The lowest results in 
serum cholesterol were recorded for group treated with $1.5 \%$ of Amla and $1.5 \%$ of Cinnamon. The lowest result in serum triglycerides was recorded for group treated with $1.5 \%$ of amla. Even, significant differences were observed between them and control negative and positive groups.

Khan et al ., (2004) demonstrate that intake of 1, 3, or $6 \mathrm{~g}$ of cinnamon per day reduces serum glucose, triglyceride, LDL cholesterol, and total cholesterol in people with type 2 diabetes and suggest that the inclusion of cinnamon in the diet of people with type 2 diabetes will reduce risk factors associated with diabetes and cardiovascular diseases.

The effect of treated rats that suffering from hyperlipidemia with different doses of Cinnamon and Amla on serum cholesterol and triglycerides were present in table (3) and fig (3a and,3b). The data showed that, serum cholesterol and triglycerides for healthy rats group (control negative) were $84.28 \pm 6.19$ and $70.27 \pm 3.7(\mathrm{mg} / \mathrm{dl})$ respectively. While for untreated hyperlipidemic group (control positive) were 174.29 \pm 10.08 and $126.41 \pm 3.62$ $(\mathrm{mg} / \mathrm{dl})$ respectively.

Askari, et al (2014) found that, cinnamon exerts decreases ALT (alanine aminotransferase) and AST (aspartat aminotransferase). In conclusion, the study suggests that taking $1500 \mathrm{mg}$ cinnamon daily may be effective in improving NAFLD (Nonalcoholic fatty liver disease characteristics).

In most cases, serum cholesterol and triglycerides were decrease for hyperlipidmic group that treated with different doses of Cinnamon and Amla. The lowest result in serum cholesterol was recorded for group treated with $1.5 \%$ of Amla and1\% of Cinnamon,while The lowest result in serum triglycerides was recorded for group treated with $1 \%$ of Amla. Even, 
significant differences were observed between them and control negative and positive group.

The effect of feeding Cinnamon and Amla on liver enzymes was shown in table (4) and fig (4a and,4b) the control negative. Serum AST, ALT and ALP for healthy rats group (control negative) were $150.83 \pm 2.48,35.66 \pm 2.8$ and 42.33 \pm 3.01 respectively. While, for untreated hyperlipidemic group (control positive) were $252.66 \pm 4.08,63.16 \pm 16$ and $62.83 \pm 4.02$ respectively.

In most cases, serum AST, ALT and ALP were decrease in hyperlipidmic group that treated with different doses of Cinnamon and Amla. The lowest serum AST and ALT were recorded for group treated with $1 \%$ of Amla, and $1.5 \%$ of Cinnamon, while the lowest in serum ALP was recorded for group treated with $1.5 \%$ of Amla and $1.5 \%$ of Cinnamon. Even, significant differences were observed between them and control negative and positive groups.

Table (1): The effect of cinnamon and amla on serum blood suger of diabetic rats ( $\mathrm{n}=6$ rats)

\begin{tabular}{||c|c|c|}
\hline \multicolumn{2}{|c|}{ Experimental group of animals } & Serum blood sugar (mg/dl) \\
\hline \multicolumn{2}{|c|}{ Control (-) } & $84.0 \pm 3.28$ \\
\hline \multicolumn{2}{|c|}{ Control (+) } & $329.66 \pm 15.08 \mathrm{a}$ \\
\hline \multirow{2}{*}{ Cinnamon } & $1 \%$ & $155.16 \pm 9.02 \mathrm{ab}$ \\
\cline { 2 - 3 } & $1.5 \%$ & $134.0 \pm 10.48 \mathrm{ab}$ \\
\hline \multirow{2}{*}{ Amla } & $1 \%$ & $153.66 \pm 7.66 \mathrm{ab}$ \\
\cline { 2 - 3 } & $1.5 \%$ & $147.0 \pm 9.36 \mathrm{ab}$ \\
\hline
\end{tabular}

Mean \pm SD 
Table(2): The effect of cinnamon and amla on serum cholesterol and triglycerides of diabetic rats. ( $\mathrm{n}=6$ rats)

\begin{tabular}{|c|c|c|c|}
\hline \multicolumn{2}{|c|}{$\begin{array}{c}\text { Experimental group of } \\
\text { animals }\end{array}$} & $\begin{array}{c}\text { Serum total cholesterol } \\
(\mathrm{mg} / \mathrm{dl})\end{array}$ & $\begin{array}{c}\text { Serum triglycerides } \\
(\mathrm{mg} / \mathrm{dl})\end{array}$ \\
\hline \multicolumn{2}{|c|}{ Control (-) } & $84.28 \pm 6.19$ & $70.27 \pm 3.78$ \\
\hline \multicolumn{2}{|c|}{ Control (+) } & $174.29 \pm 10.08 \mathrm{a}$ & $126.41 \pm 3.62 \mathrm{a}$ \\
\hline \multirow[t]{2}{*}{ Cinnamon } & $1 \%$ & ab148.02 \pm 13.54 & $125.39 \pm 3.96 \mathrm{a}$ \\
\hline & $1.5 \%$ & $155.91 \pm 8.47 \mathrm{a}$ & $119.03 \pm 9.56 \mathrm{ab}$ \\
\hline \multirow[t]{2}{*}{ Amla } & $1 \%$ & $148.45 \pm 2.68 \mathrm{ab}$ & $109.96 \pm 8.20 \mathrm{ab}$ \\
\hline & 1.5 & $132.28 \pm 4.65 \mathrm{ab}$ & $115.70 \pm 3.30 \mathrm{ab}$ \\
\hline
\end{tabular}

Mean \pm SD

Table(3): The effect of cinnamon and amla on serum cholesterol and triglycerides of hyperlipidemic rats. ( $n=6$ rats)

\begin{tabular}{|c|c|c|c|}
\hline \multicolumn{2}{|c|}{$\begin{array}{c}\text { Experimental group of } \\
\text { animals }\end{array}$} & $\begin{array}{c}\text { Serum total } \\
\text { cholesterol }(\mathbf{m g} / \mathbf{d l})\end{array}$ & $\begin{array}{c}\text { Serum triglycerides } \\
(\mathbf{m g} / \mathbf{d l})\end{array}$ \\
\hline \hline \multicolumn{2}{|c|}{ Control (+) } & $84.28 \pm 6.19$ & $70.27 \pm 3.78$ \\
\hline \multicolumn{2}{|c|}{ Control (-) } & $304.17 \pm 30.25$ & $140.07 \pm 3.73$ \\
\hline \multirow{2}{*}{ Cinnamon } & $1 \%$ & $279.04 \pm 27.55 \mathrm{ac}$ & $99.14 \pm 6.62 \mathrm{ac}$ \\
\cline { 2 - 4 } & $1.5 \%$ & $224.97 \pm 22.39 \mathrm{ac}$ & $103.03 \pm 8.44 \mathrm{ac}$ \\
\hline \multirow{2}{*}{ Amla } & $1 \%$ & $243.52 \pm 6.46 \mathrm{ac}$ & $92.61 \pm 6.08 \mathrm{ac}$ \\
\cline { 2 - 4 } & $1.5 \%$ & $223.47 \pm 26.76 \mathrm{ac}$ & $89.07 \pm 5.43 \mathrm{ac}$ \\
\hline
\end{tabular}

Mean \pm SD 
J. Environ. Sci.

Institute of Environmental Studies and Research - Ain Shams University

Table (4): The effect of cinnamon and amla on serum AST, ALT and ALP of hyperlipidemic rats. ( $\mathrm{n}=6$ rats $)$.

\begin{tabular}{|c|c|c|c|c|}
\hline $\begin{array}{c}\text { Experimental group of } \\
\text { animals }\end{array}$ & $\begin{array}{c}\text { AST } \\
(\mathbf{m g} / \mathbf{d l})\end{array}$ & $\begin{array}{c}\text { ALT } \\
(\mathbf{m g} / \mathbf{d l})\end{array}$ & $\begin{array}{c}\text { ALP } \\
(\mathbf{m g} / \mathbf{d l})\end{array}$ \\
\hline \hline \multicolumn{2}{|c|}{ Control (-) } & $150.83 \pm 2.48$ & $35.66 \pm 2.8$ & $42.33 \pm 3.01$ \\
\hline \multicolumn{2}{|c|}{ Control (+) } & $252.66 \pm 4.08 \mathrm{ab}$ & $63.16 \pm 16 \mathrm{ab}$ & $62.83 \pm 4.02 \mathrm{ab}$ \\
\hline Cinnamon & $1 \%$ & $201.66 \pm 25.37 \mathrm{ab}$ & $56.66 \pm 3.88 \mathrm{ab}$ & $53.0 \pm 2.75 \mathrm{ab}$ \\
\cline { 2 - 5 } & $1.5 \%$ & $177.0 \pm 24.85 \mathrm{~b}$ & $50.66 \pm 4.08 \mathrm{ab}$ & $44.33 \pm 3.01 \mathrm{~b}$ \\
\hline \multirow{2}{*yyyy}{ Amla } & $1 \%$ & $172.5 \pm 18.38 \mathrm{~b}$ & $48.66 \pm 2.42 \mathrm{ab}$ & $55.16 \pm 7.36 \mathrm{ab}$ \\
\cline { 2 - 5 } & $1.5 \%$ & $179.66 \pm 50 \mathrm{~b}$ & $70.0 \pm 4.33 \mathrm{ab}$ & $46.33 \pm 5.61 \mathrm{~b}$ \\
\hline
\end{tabular}

Mean \pm SD

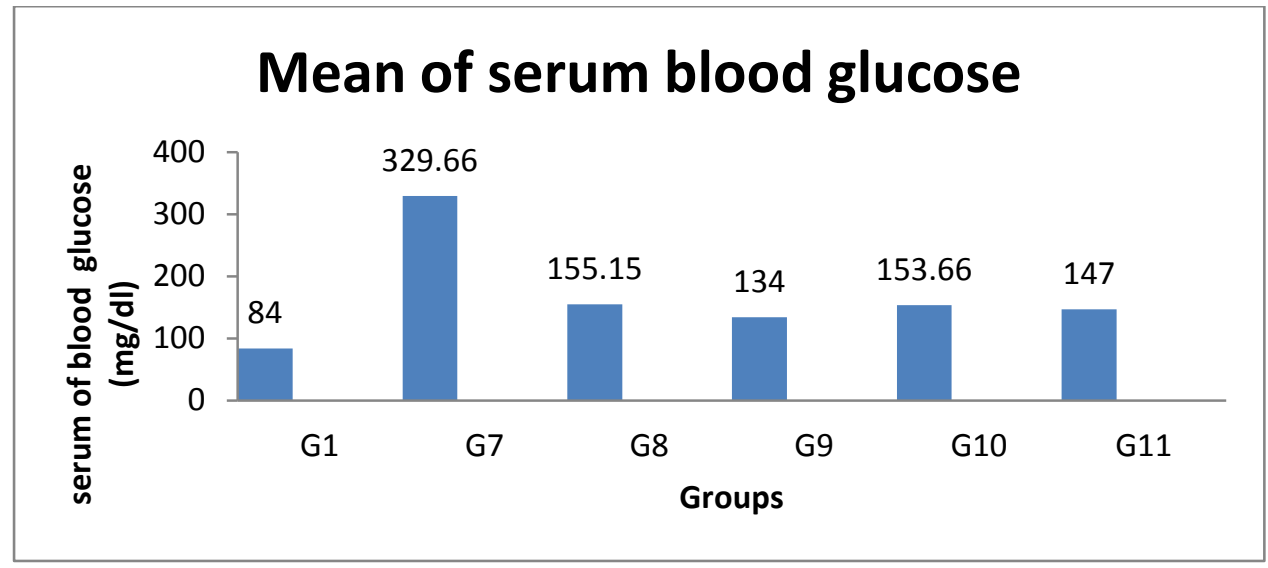

Figure(1): The effect of different doses of cinnamon and amla on serum blood sugar of diabetic rats.

G1: Control (-) normal rats fed on basal diet

G7: Control (+) diabetic rats fed on basal diet

G8: Diabetic rats fed on basal diet $+1 \%$ cinnamon

G9: Diabetic rats fed on basal diet $+1.5 \%$ cinnamon

G10: Diabetic rats fed on basal diet $+1 \%$ amla

G11: Diabetic rats fed on basal diet $+1.5 \%$ amla 


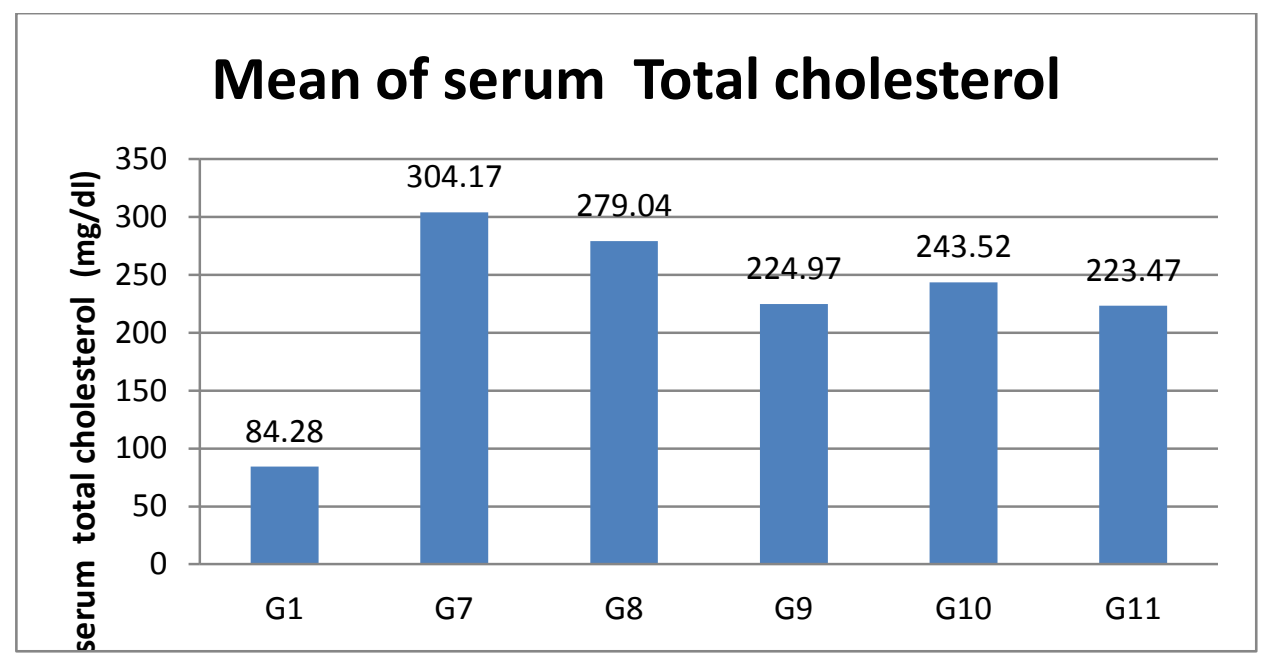

Groups

Figure (2.a): The effect of different doses of cinnamon and amla on serum total cholesterol of diabetic rats.

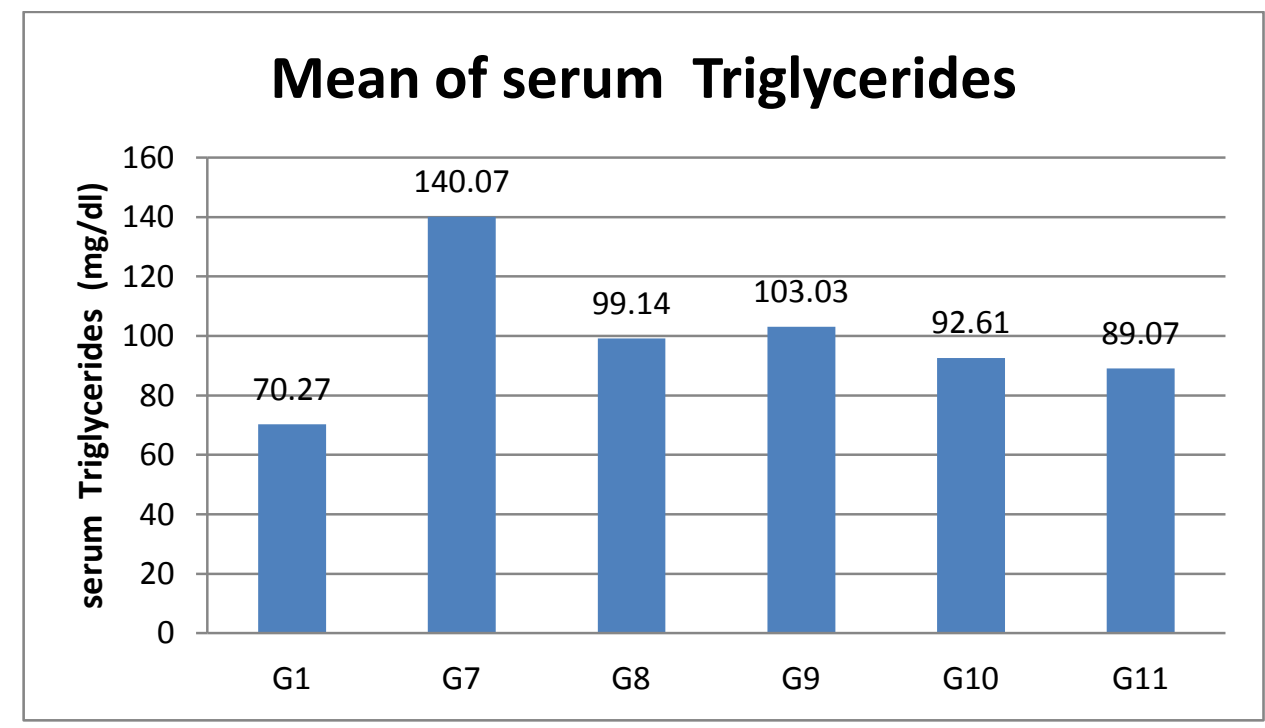

Groups

Figure (2.b): The effect of different doses of cinnamon and amla on serum triglycerides of diabetic rats. 
J. Environ. Sci.

Institute of Environmental Studies and Research - Ain Shams University

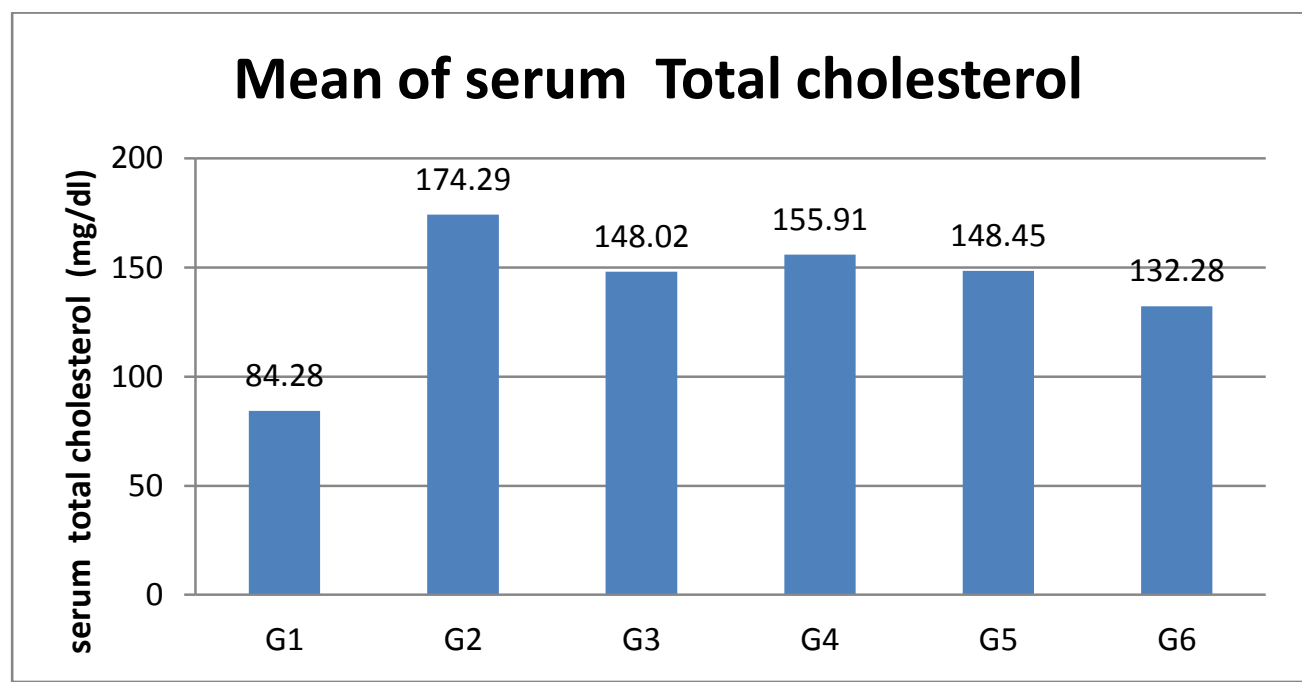

\section{Groups}

Figure (3.a): The effect of different doses of cinnamon and amla on serum total cholesterol of hyperlipidemic rats.

G1: Control (-) normal rats fed on basal diet

G2: Control (+) hyperlipidemic rats fed on basal diet

G3: Hyperlipidemic rats fed on high fat diet $+1 \%$ cinnamon

G4: Hyperlipidemic rats fed on high fat diet $+1.5 \%$ cinnamon

G5: Hyperlipidemic rats fed on high fat diet $+1 \%$ amla

G6: Hyperlipidemic rats fed on high fat diet $+1.5 \%$ amla 


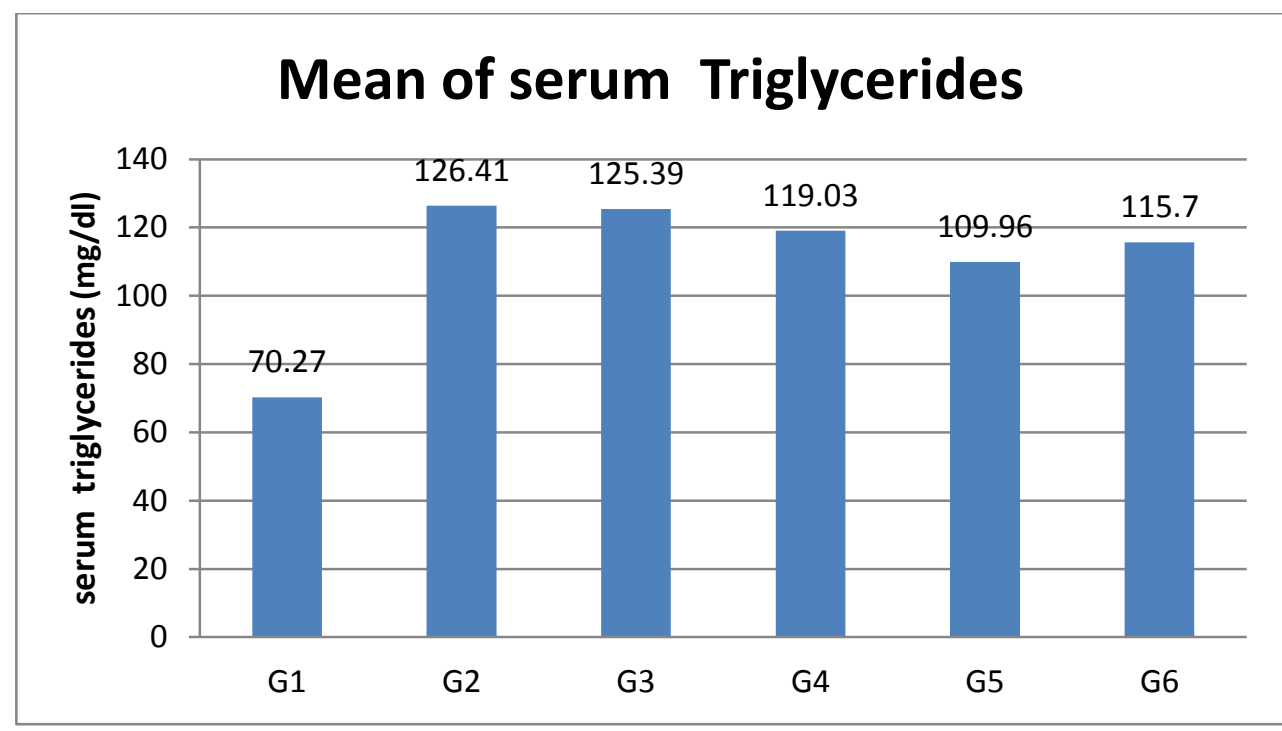

Groups

Figure (3.b): The effect of different doses of cinnamon and amla on serum triglycerides of hyperlipidemic rats.

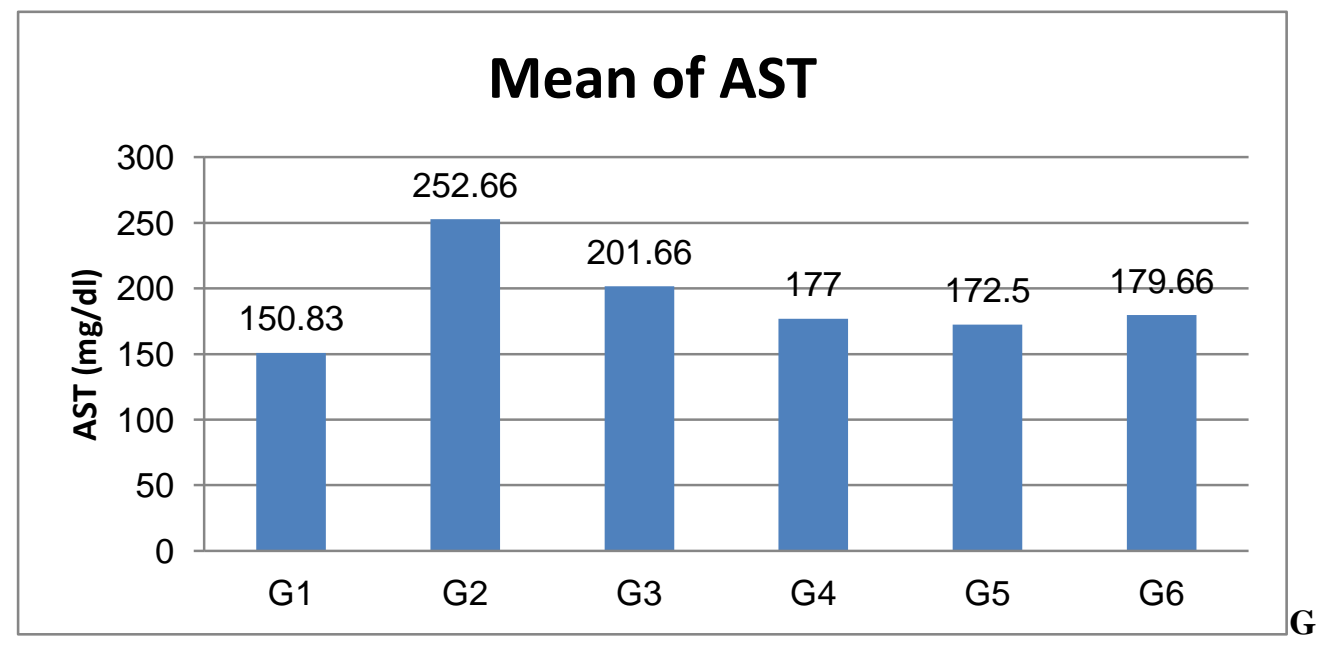

Groups

Figure (4.a): The effect of different doses of cinnamon and amla on (AST) of hyperlipidemic rats. 
J. Environ. Sci.

Institute of Environmental Studies and Research - Ain Shams University

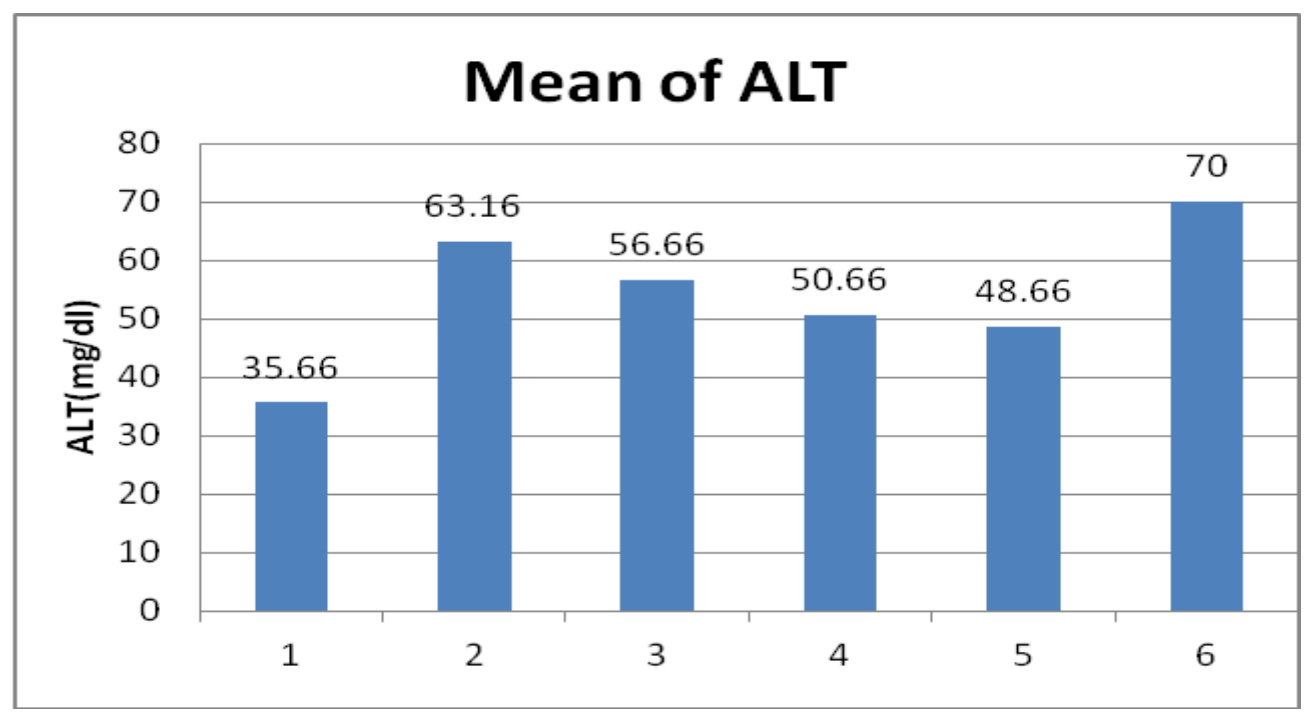

Groups

Figure (4.b): The effect of different doses of cinnamon and amla on (ALT) of hyperlipidemic rats.

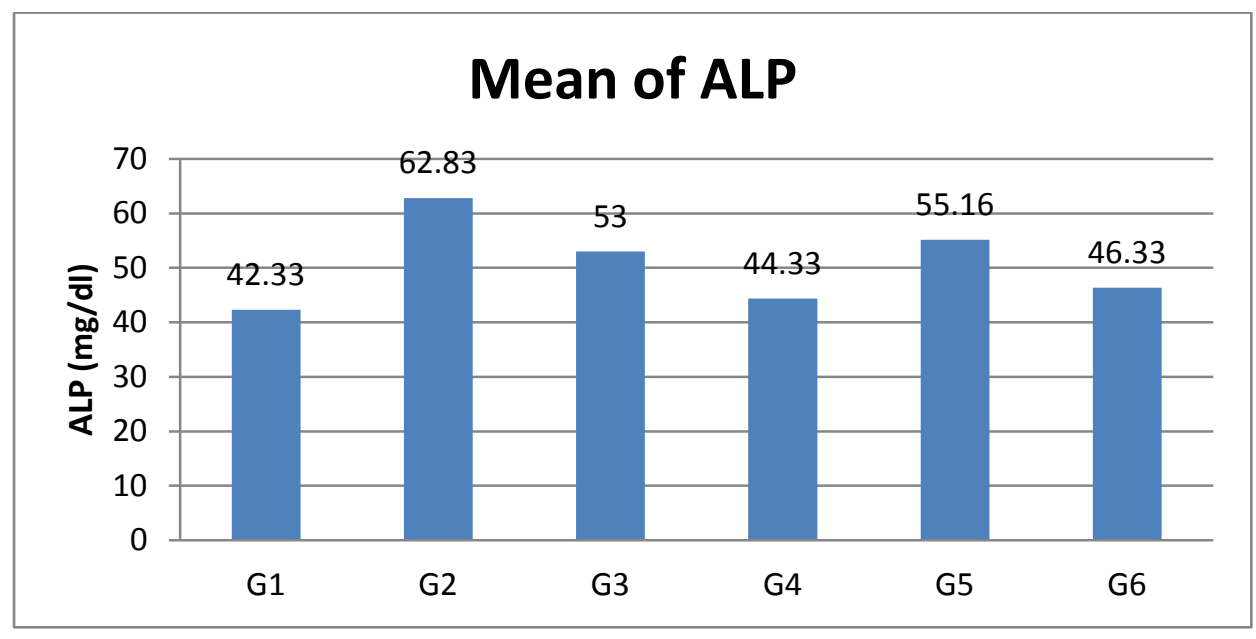

\section{Groups}

Figure (4.c): The effect of different doses of cinnamon and amla on (ALP) of hyperlipidemic rats. 


\section{CONCLUTION}

This study aimed to decreasing blood glucose and hyperlipidemia using dry Cinnamon and Amla.

- Serum glucose for diabetic groups decreased compared to control (+).

- The rats of all groups showed higher values than control (-) and lower compared control (+), for total cholesterol and TG. Groups feed on 1.5\% of amla and $1.5 \%$ cinnamon showed a lower value than others groups compared to control (+).

- Our results for AST indicate that, there is non-significant difference between control (-) and all groups.

- The concentration of ALT showed a non significant difference between control (+) and all groups

\section{REFERENCES}

A.O.A.C (1990): Association of Official Analytical Chemists. Official Methods of Analysis of Association of Official Analytical Chemists. Washington, D.C., USA.

AIN (1993): American Institute of Nutrition (AIN), Purified diet for Laboratory Rodent. J. Nutr., 123:1939-1951.

Allain, C. C. (1974): Cholesterol enzymatic colorimetric Method. J. Clin. Chem., 2: 470.

American Diabetes Association (2001): Screening for diabetes. Diabetes care 24 (supply):521-524.

Askari, F; Rashidkhani, B. and Hekmatdoost, A. (2014): Cinnamon may have therapeutic benefits on lipid profile, liver enzymes, insulin resistance, and high-sensitivity C-reactive protein in nonalcoholic fatty liver disease patients. Nutr. Res. 34(2):143-8. 
Baliga, S.; Dsouza, M. and Jerome, J. (2011): Amla ( Emblica officinalis ) Gaertn, a wonder berry in the treatment and prevention of cancer. May; 20 ( 3 ): 225 - 239.

Beirao, D.A.; Costa, M. L.; Januario, M.I .N.; Simao, F. M. S.and Leitao, A. E. B. (2005) Characterisation of inulin from chicory and saisify cultivated in Portugal. Alimentos. E. Nutr., 16 (3): 221-225.

Dhanabal, S.P.; Sureshkumar, M.; Ramanathan, M. and Suresh, B. (2005): Hypoglycemic effect of ethanolic extract of Musa sapientum on alloxan induced diabetes mellitus in rats and its relation with antioxidant potential. J. Herb Pharmacother; 5 (2): 7-19.

Fossatip, S. F. and Prancipel, R. (1982): Triglycerides determination after enzymatic hydorolysis. Clin. Chem., 28: 2077.

James, C. S. (1995): Analytical chemistry of foods. Publ. Blacki Academic and Professional, an imprint of Chapman and Hall, Wester Cleddens Road, Bishop Briggs, Glasgow G642 NZ.

Khan, A.; Flanagan, V.P.; Schoene, N.W. and Graves , D. J. (2004): Isolation and characterization of polyphenol type -A polymers from cinnamon with insulin-like biological activity. J. Agric. Food Chem., Jan. 14; 52 (1) :65 - 70. American Diabetes Association (2001): Screening for diabetes .Diabetes care 24 (supply):521524.

Kirk, R.S.and Sawyer, R. (1991): Pearson's composition and analysis of food. 9 th ed., Longman Singapore publishers, Singapore. pp. 330-333.

Krishnaveni, M. and Mirunalini, S. (2010): Therapeutic potential of (Phyllanthus emblica "amla" ) the ayurvedic wonder. Journal of Basic and Clinical Physiology and pharmacology, 21 (1): 93-105.

Lee, R.D. and Nieman, D.C. (2003): nutritional assessment. 3rd. Pub, by Mc. Graw. Hill. Avenue of the Americans, New York .s287.

Reeves, P. G.; Nielson, F. H. and Fahmy, G. C.(1993): Reports of the American Institute of Nutrition, Adhoc Wiling Committee on reformulation of the AIN 93. Rodent Diet. J. Nutri., 123: 19391951. 
Reitman, S. and Frankel, S. (1957): A color metric method for the determination of serum glutamic oxaloacetic and glutamic pyruvic transaminases. Am. J. Clin. Path, 28: 56- 63.

Roy, S. E. (1970): Colorimetric determination of serum alkaline phosphatase. Clin. Chem. '16:431-432.

SAS (1988): SAS User's Guide Statistics, Cary, NC: SAS Institute.

Schernthaner, G. and Schernthaner, GH.(2013): Diabetic nephropathy: new approaches for improving glycemic control and reducing risk. J. Nephrol. US National Library of MedicineNational Institutes of Health -Dec;26(6):975-85.

Singab, A.N.; Youssef, F.S.and Ashour, M.L. (2014): Medicinal Plants with Potential Antidiabetic Activity and their Assessment. Med Aromat Plants 3:151.

Soliman, M, Mohamed M.A. and Samir, A.E. (2013): cinnamon extract regulates gene expression of lipid and carbohydrate metabolism in reptozotocin induced diabetic wistar rats. American Journal of Biochemistry and Biotechnology, 9 (2): 172-182, 2013.

Solun, B.; Marcoviciu, D. and Dicker, D. (2013): Dipeptidyl peptidase-4 inhibitors and their effects on the cardiovascular system.. US National Library of MedicineNational Institutes of Health Aug;15 (8):382.

Trinder, P. (1969): Glucose enzymatic colorimeteric method. J. Ann. Clin. Biochem., 6: 24.

Watson, P.h. D. C. (2001): Vegetables, Fruits and Herbs in Health Promotion.1st. Pubs, by CRC. Press. LLC. New York.212-214.

WHO (1980): Expert Committee on Diabetes Mellitus, second report. Technical report series 646 World Health Organization, Geneva. 


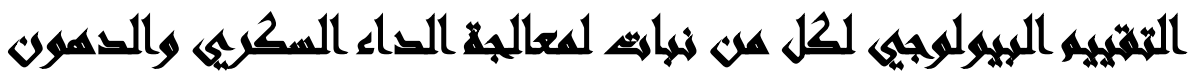

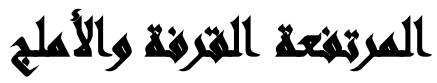

[7]

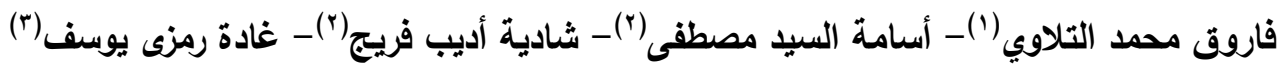

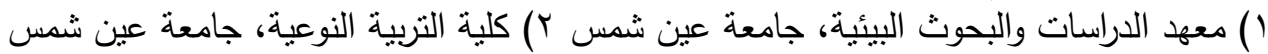

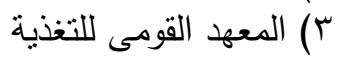

\section{المستخلم:}

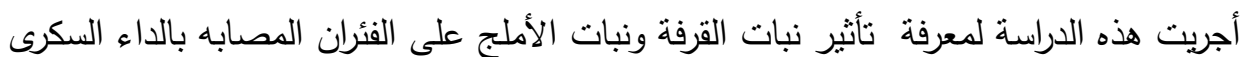

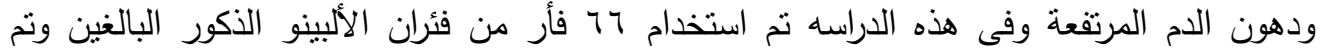

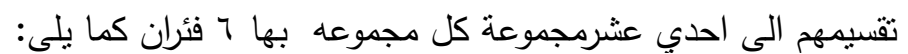

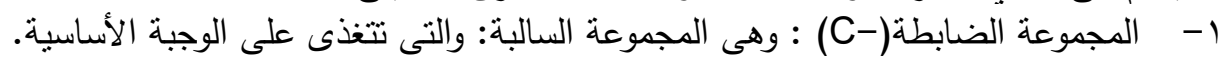

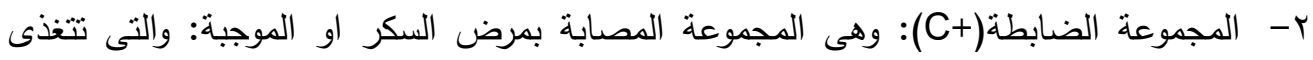
على الوجبة الأساسية

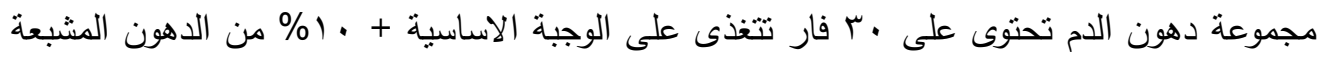

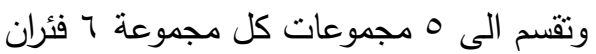
المجموعة التانية: مصابة بدهون دم وتتغذى على الوجبة الاساسية فقط (الضابطة الموجبة)

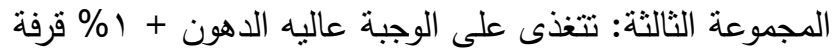

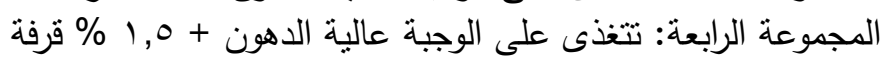

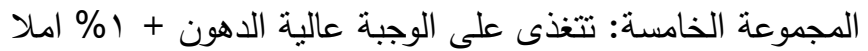

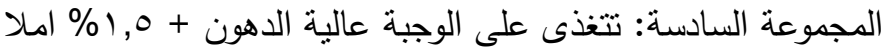

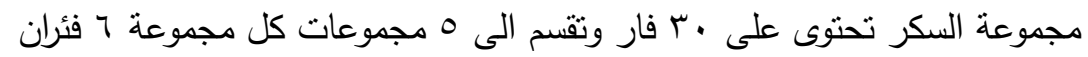

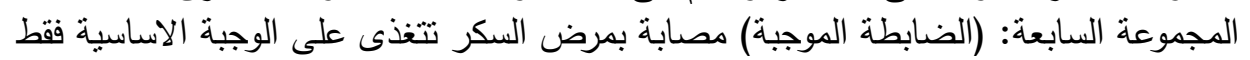

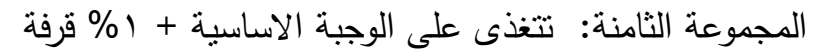

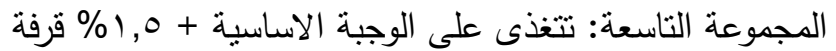

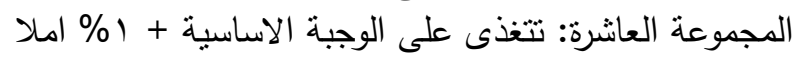

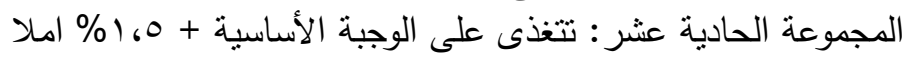
وقد تم تغذية الفئران لمدة ؛ أسابيع وبعد انتهاء التجربة تم ذبح الفئران وسحب عينات التهات الدم منها وعمل التحاليل الكميائية المطلوبة. 


$$
\text { وكانت النتائج كما يلي: }
$$

من خلال الدراسه نجد أن القرفة والاملج يلعبان دورا هاما في انخفاض مستوى سكر ودهون الدام

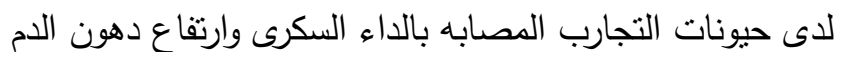

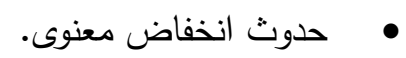

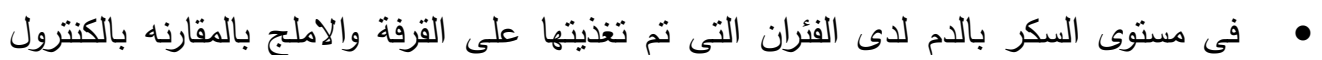
الموجبه والمغذاه على الوجبه الأساسيه.

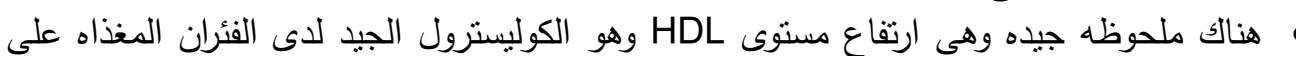
القرفة وأيضا والاملج عند الفئران المصابة بارتفاع دهون الدام. 